\title{
Kiliophora novozhilovii sp. nov. and first record of Zanclospora cf. novae-zelandiae (asexual ascomycetes) from Vietnam
}

\section{Vadim A. Mel'nik ${ }^{1}$, Uwe Braun ${ }^{2 *} \&$ Alina V. Alexandrova ${ }^{3,4}$}

${ }^{1}$ Laboratory of the Systematics and Geography of Fungi, Komarov Botanical Institute, Russian Academy of Sciences, Professor Popov Street 2, St. Petersburg, 197376, Russia

${ }^{2}$ Martin Luther University, Institute of Biology, Department of Geobotany and Botanical Garden, Herbarium, Neuwerk 21, 06099 Halle (Saale), Germany

${ }^{3}$ Moscow State Lomonosov University, Department of Biology, Lenin Hill Street 1, 12, Moscow 119234 , Russia

${ }^{4}$ Joint Vietnam-Russian Tropical Research and Technological Centre, Nguyen Van Huyen, Nghia Do, Cau Giau, Hanoi, Vietnam

Received 21 June 2016 / Accepted 11 July 2016 / Published 17 July 2016

Mel'nik, V.A., Braun, U. \& Alexandrova, A.V. 2016. Kiliophora novozhilovii sp. nov. and first record of Zanclospora cf. novae-zelandiae (asexual ascomycetes) from Vietnam. - Mycobiota 6: 47-54. doi: 10.12664/ mycobiota.2016.06.05

\begin{abstract}
The new species Kiliophora novozhilovii (Ascomycota, Incertae sedis), found in Vietnam on a dead leaf of an unidentified tree, is described, illustrated, compared with other species assigned to Kiliophora, and keyed out. The asexual, hyphomycetous ascomycete Zanclospora cf. novae-zelandiae has been found in Vietnam for the first time. This hitherto rarely encountered species is described and illustrated based on the Vietnamese collection, and its taxonomy is briefly discussed.
\end{abstract}

Key words: distribution, hyphomycetes, Kiliophora, new species, Southeast Asia, Vietnam, Zanclospora

\section{Introduction}

Since 2010 Russian mycologists from the Komarov Botanical Institute, Russian Academy of Sciences (St. Petersburg) and Moscow State Lomonosov University have been engaged in comprehensive mycological explorations in Vietnam. The scope of a research program of the Vietnam-Russian Tropical Research and Technological Centre aims to improve the knowledge of the mycota of Vietnam, a tropical country in Southeast Asia with high

\footnotetext{
*Corresponding author: e-mail: uwe.braun@botanik.uni-halle.de
} 
but little explored fungal diversity. During the course of these explorations, numerous micromycetes have been collected, including several taxonomic novelties and many new records for Vietnam (Mel'nik 2011, 2012a, b, 2013; Melnik et al. 2012, 2013a, b, c, d, 2014a, b, 2015a, b, c, 2016; Alexandrova et al. 2013; Mel'nik \& Braun 2013; Mel'nik $\&$ Crous 2014). The present contribution to a better knowledge of Vietnamese fungi encompasses two asexual hyphomycetous ascomycetes, viz. a new species and a new record for Vietnam.

\section{Material and methods}

Fresh samples collected during the course of field trips in Vietnam were dried at room temperature. The material was later mounted in distilled water, and examined as well as photographed using a Zeiss microscope, Stemi 2000CS, and Axio Imager A1 equipped with Nomarski differential interference contrast optics. Identification was carried out through comparison with current taxonomic works dealing with the genera and species concerned. The sizes of conidiophores, conidia and other characters are based on 30 measurements per structure with extremes given in brackets. The examined specimens are deposited in the herbarium of the Komarov Botanical Institute, St. Petersburg, Russia (LE).

\section{Results and discussion}

Kiliophora novozhilovii Melnik, U. Braun \& A.V. Alexandrova, sp. nov.

Fig. 1 MycoBank MB 817456

Etymology: named after Yu. K. Novozhilov, collector of numerous micromycetes in Vietnam.

Colonies effuse, hairy, blackish. Conidiophores macronematous, mononematous, setiform, to $140 \mu \mathrm{m}$ high, 6-9 $\mu \mathrm{m}$ wide at the base, gradually tapered towards the apex, 6-7 $\mu \mathrm{m}$ wide, apex swollen, hemispherical, $8-10 \mu \mathrm{m}$ diam., septate, brown, smooth, uppermost cell of the conidiophore pale brown. Conidiogenous cells discrete, pleurogenous, arising from intercalary cells, through minute pores, globose to subglobose, $8-10 \mu \mathrm{m}$ diam., enteroblastic, polytretic, hyaline to pale brown, thin-walled, smooth. Conidia solitary, oblong-ellipsoid to slightly short clavate or short obclavate, 14.4-16 × 2.6-3.2 $\mu \mathrm{m}$, aseptate, hyaline, thin-walled, smooth, ends conically attenuated, with minute polar denticle-like projections, $1.2-1.8 \mu \mathrm{m}$ wide at the base and $0.8-1.0 \mu \mathrm{m}$ high.

Type on a dry leaf of an unidentified tree, VIETNAM, DONG NAI PROVINCE, Cat Tien National Park, sector Nam Cat Tien, Ta Lai, right bank of river Dong Nai, near the plot "Ficus", which is under the canopy of robust trees of Ficus sp. (Moraceae) growing between Lagerstroemia calyculata (Lythraceae) and Dalbergia multiflora (Fabaceae), 11 26'08" N, 107²5'27" E, 2 Jan 2011, leg. Yu.K. Novozhilov (holotype, LE 264220).

The present hyphomycete recently found in Vietnam on a shed leaf of an unidentified deciduous tree could be readily assigned to Kiliophora Kuthub. \& Nawawi (Kuthubutheen \& Nawawi 1993: 239) [= Danaëa Caneva \& Rambelli (Caneva \& Rambelli 1981: 47), nom. illeg.], with $K$. fusispora Kuthub. \& Nawawi as the type species. The genus is 
characterized by having discrete, pleurogenous, enteroblastic, polytretic conidiogenous cells that arise between about the middle of the setiform conidiophores and a terminal portion devoid of conidiogenous cells, and fusiform to spindle-shaped, aseptate, hyaline to pale brown conidia with denticle-like projections at both ends. Kuthubutheen \& Nawawi (1993) introduced the new combination K. ubiensis (Caneva \& Rambelli)
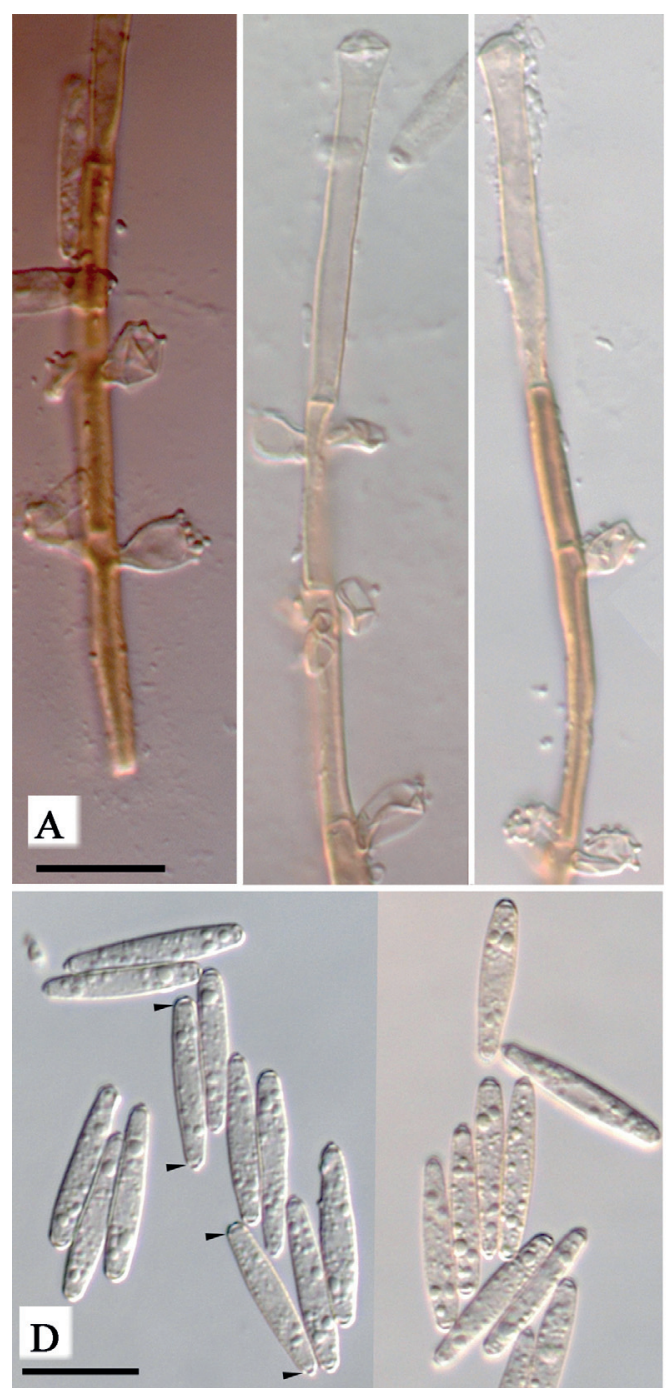
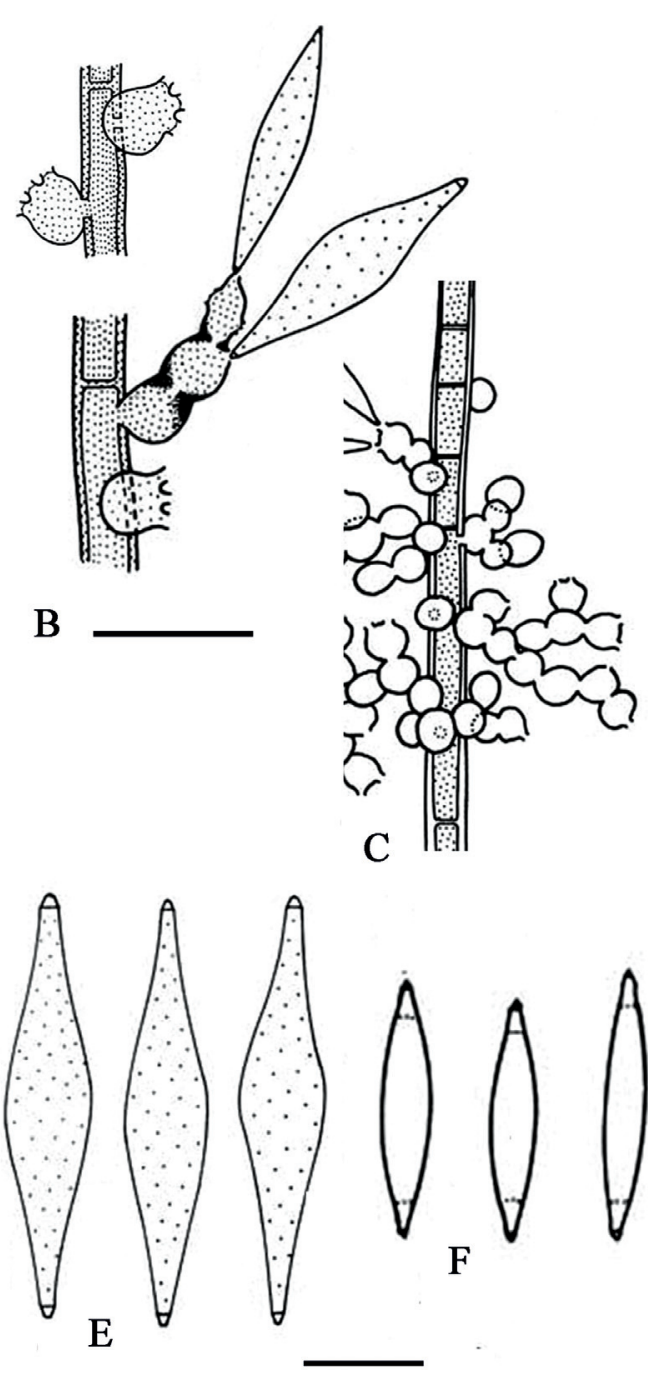

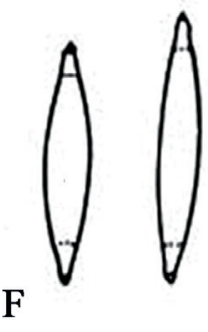

Fig. 1. Kiliophora novozhilovii sp. nov. (A and D, LE 264220, holotype), K. fusispora (B and E, based on Kuthubutheen \& Nawawi 1993: 240, Fig. 1, reproduced with permission), and K. ubiensis (C and F, based on Kuthubutheen \& Nawawi 1993: 244, Fig. 9, reproduced with permission). A-C. Conidiophores and conidiogenous cells. D-F. Conidia with minute polar projections. Scale bars: A and D $=10 \mu \mathrm{m}, \mathrm{B}, \mathrm{C}, \mathrm{E}$, and $\mathrm{F}=20 \mu \mathrm{m}$ 
Kuthub. \& Nawawi, based on Danaëa ubiensis Caneva \& Rambelli (Caneva \& Rambelli 1981). The conidia of $K$. ubiensis have similar denticle-like projections at both ends. Cruz et al. (2007) recorded this species on leaf litter in Brazil and provided measurements of conidiogenous cells $(8-10 \mu \mathrm{m}$ diam.) and conidia $(21-25 \times 3-5 \mu \mathrm{m})$. Hidayat $\&$ Harahap (2014) found K. ubiensis on leaf litter of Shorea sp. in Indonesia, cultured this species and accomplished molecular sequence analyses. The phylogenetic affinity of $K$. ubiensis, which is not the type species of Kiliophora, was demonstrated to be within the Amphisphaeriaceae (Xylariales). The conidia in the material from Indonesia were distinctly smaller in comparison with type material $(7-17 \times 2-4 \mu \mathrm{m}$, versus $18-25 \times 3-5 \mu \mathrm{m})$ suggesting that an undescribed species similar to but not conspecific with $K$. ubiensis might be involved. Kiliophora novozhilovii is easily distinguishable from the two other species of Kiliophora by its colorless conidia with quite different shape and size (oblongellipsoid to slightly short clavate or obclavate, 14.4-16 $\times 2.6-3.2 \mu \mathrm{m}$, versus subhyaline to pale brown, fusiform-ventricose, 30-37 $\times 6-8 \mu \mathrm{m}$ in $K$. fusispora and subhyaline to pale grayish brown in mass, fusiform, $18-25 \times 2-5 \mu \mathrm{m}$ in $K$. ubiensis). In addition, there are differences in the conidiogenous cells. In $K$. novozhilovii, they are 8-10 $\mu \mathrm{m}$ wide and do not proliferate, i.e. they are consistently formed singly. K. ubiensis is characterized by smaller (3-6 $\mu \mathrm{m}$ diam.), frequently proliferating conidiogenous cells forming branched chains of such cells. The conidiogenous cells of $K$. novozhilovii resemble those of $K$. fusispora, but they do not proliferate. In summary, $K$. fusispora, $K$. ubiensis and the new species $K$. novozhilovii are undoubtedly congeneric agreeing in basic characters of conidiophores, conidiogenous cells, conidiogenesis, and conidia, but clearly differ from each another in the shape and size of conidia and in some details of the conidiogenous cells. The presence of polar projections in conidia seems to be an important, hitherto little emphasized generic trait of Kiliophora.

\section{Key to the species of Kiliophora}

1 Conidiogenous cells initially simple and solitary, later repeatedly proliferating through one or more of the conidiogenous loci of the previously formed cells to produce branched chains of conidiogenous cells; conidia $18-25 \times 2-5 \mu \mathrm{m}$, fusiform, with more or less pointed projections at both end $\ldots \ldots \ldots \ldots \ldots \ldots$ ubiensis

$1^{*}$ Conidiogenous cells consistently solitary, non-proliferating or only occasionally proliferating; conidia either longer $(>29)$ or shorter $(<17 \mu \mathrm{m})$, projections not pointed

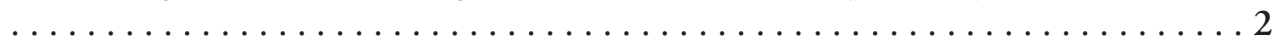

2 Conidiogenous cells simple or occasionally proliferating; conidia large, $30-37 \times 6-8$ $\mu \mathrm{m}$; fusiform-ventricose, projections $2-2.5 \mu \mathrm{m}$ wide $\ldots \ldots \ldots \ldots \ldots$. fusispora

$2 *$ Conidiogenous cells consistently solitary, not proliferating; conidia 14.4-16 × 2.6-3.2 $\mu \mathrm{m}$, oblong-ellipsoid to slightly short clavate or short obclavate, projections $1.2-1.8 \mu \mathrm{m}$

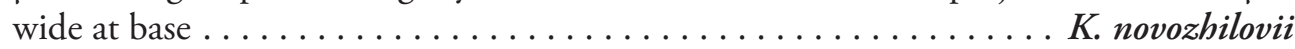


Zanclospora cf. novae-zelandiae S. Hughes \& W.B. Kendr., New Zealand J. Bot. 3: 153, 1965.

Fig. 2

Colonies effuse, hairy, dark brown, composed of scattered trichoid-setiform conidiophores. Conidiophores erect, straight, rarely slightly curved, attenuated towards the subacute apex, unbranched, to $520 \mu \mathrm{m}$ long, 8-10 $\mu \mathrm{m}$ wide at the base, 5.5-6 $\mu \mathrm{m}$ wide in the middle, with up to 30 septa, uniformly brown throughout, distinctly thick-walled throughout, smooth. Fertile region of the conidiophore situated about 80-100 $\mu \mathrm{m}$ below the apex. Conidiogenous cells monophialidic, discrete, formed in 4-5 whorls, lageniform or

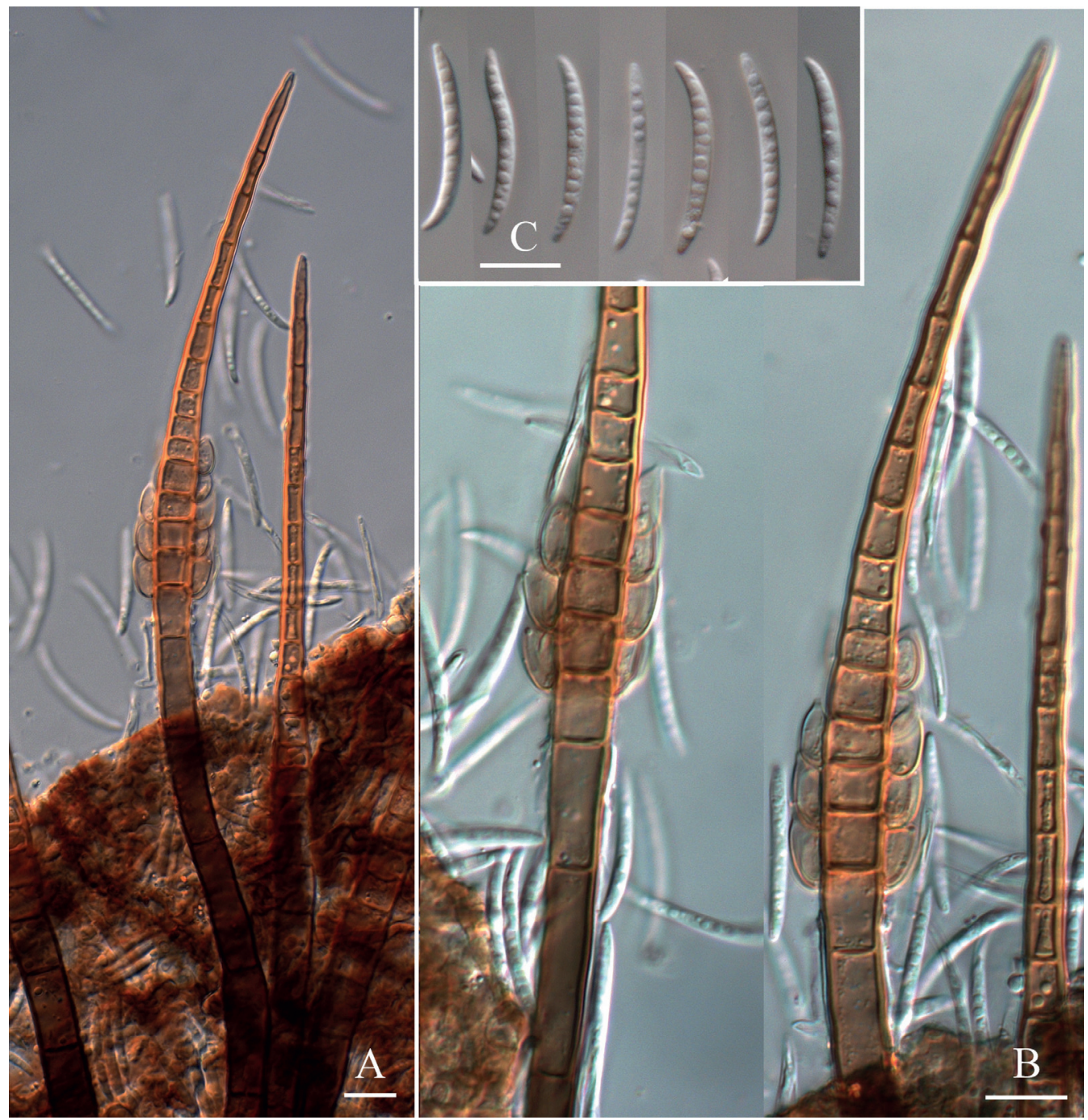

Fig. 2. Zanclospora cf. novae-zelandiae (LE 264617): A, B - conidiophores and conidiogenous cells, $\mathrm{C}-$ conidia. Scale bars $=10 \mu \mathrm{m}$ 
ampulliform, sessile, appressed to the supporting conidiophore, subhyaline to pale brown, smooth, 10-12 $\times 4-5.5 \mu \mathrm{m}, 1-1.8 \mu \mathrm{m}$ wide at the tapered open distal end. Conidia falcate, often strongly curved, 22-24(-26) $\times 2-2.4 \mu \mathrm{m}$, aseptate, thin-walled, smooth, hyaline, with up to 12 oil globules, imitating the presence of septa, aggregated in cloudy, subhyaline, spherical mucilaginous aggregations.

Specimen examined - On bark of an unidentified tree, VIETNAM, LAM DONG PROVINCE, Bi Dup - Nui Ba Natural Reserve, in the vicinity of cordon Giang Ly, evergreen polydominant tropical mountain forest predominant by fagaceous trees and

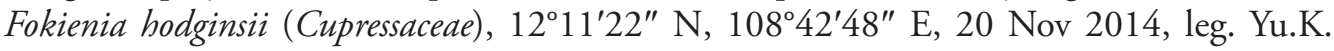
Novozhilov (LE 264617).

Hughes \& Kendrick (1965) described the genus Zanclospora and its type species $Z$. novae-zelandiae from New Zealand based on material collected on bark of Nothofagus solandri. The conidiophores were described as simple or branched, distal sterile ends "ornamented with numerous disc-like excrescences up to $1.6 \mu \mathrm{m}$ wide and $0.4 \mu \mathrm{m}$ high". $Z$. novae-zelandiae has been recorded and described by several authors from different parts of the world (Matsushima 1975, Japan; Schoknecht \& Crane 1983, Canada; Rao \& de Hoog 1986, India; Chang 1990, Taiwan; Raja et al. 2007, USA; Almeida et al. 2013, Brazil). Calduch et al. (2007) and Almeida et al. (2013) offered keys to the species of Zanclospora. Using these keys and comparing the characters of the Vietnamese collection with descriptions of all species assigned to Zanclospora led directly to $Z$. novae-zelandiae, although some discrepancies came to light. The conidial size described by several authors is rather variable, reflecting a wide range [Hughes \& Kendrick (1965) - 18-35 × 1.6-2.6 $\mu \mathrm{m}$; Matsushima (1975) - 25-35 × 2.5-3.5 $\mu \mathrm{m}$; Schoknecht \& Crane (1983) $-15.5-$ $23 \times 2.3-3.3 \mu \mathrm{m}$; Chang $(1990)-19-30 \times 1-2.5 \mu \mathrm{m}$; Almeida et al. $(2013)-10-16.5$ $\times 1-2 \mu \mathrm{m}]$. The conidial size in the material from Vietnam is within the variation given in the original description, but the conidiophores are consistently unbranched. However, uniformly unbranched conidiophores were also described by other authors, e.g. Almeida et al. (2013). The walls of the conidiophores in the Vietnamese sample are smooth throughout. However, the characteristically verrucose wall of the upper sterile portion of the conidiophores emphasized in the original description of $Z$. novae-zelandiae was not mentioned in all other secondary descriptions. These differences between the particular collections from different countries might reflect a strong variability of a single species or could point to several cryptic species. This question can currently not be answered. Sufficient in vitro data for this species and corresponding analyses of sequence data are lacking. Therefore, we prefer to assign the new Vietnamese specimen to $Z$. novae-zelandiae, at least tentatively.

Zanclospora novae-zelandiae is the second species of Zanclospora recorded from Vietnam. Mel'nik et al. (2014) reported Z. bonfinensis D.A.C. Almeida, Gusmão \& M.F.O. Marques from Dong Nai Nature Reserve, Dong Nai Province (on leaf litter of an unidentified tree, 14 Nov 2011, leg. Yu.K. Novozhilov, LE 264125). 
Acknowledgements. Nguyen Van Dien, director of the Cat Tien National Park, and Le Van Huong, director of the Bi Dup - Nui Ba National Park, are thanked for help in the organization of field expeditions in these National Parks. We are much obliged to Yu.K. Novozhilov (Laboratory of the Systematics and Geography of Fungi, Komarov Botanical Institute, Russian Academy of Sciences, St. Petersburg, Russia) for collecting and providing the samples of Kiliophora novozhilovii and Zanclospora cf. novae-zelandiae. The present examinations were carried out within the scope of an institutional research project (no. 01201255603) of the Komarov Botanical Institute of the Russian Academy of Sciences. Expedition and laboratory works were supported by the Program Ecolan-1.2 of the Joint Vietnamese-Russian Tropical Scientific and Technological Centre. A.V. Alexandrova's activities were supported by the Russian Science Foundation (project N14-50-00029). The technical treatment of the examined collections was accomplished with technical support provided by The Core Facility Center "Cell and Molecular Technologies in Plant Science" of the Komarov Botanical Institute, Russian Academy of Sciences" within the scope of a state assignment for Komarov Botanical Institute, "Mycobiota of South Vietnam" (no. 01201255603), and for Moscow State University (theme no. 012011 57318).

\section{References}

Alexandrova, A.V., Braun, U. \& Mel'nik, V.A. 2013. Pyricularia contorta sp. nov. - a new species from Vietnam. - Schlechtendalia 25: 73-76.

Almeida, D.A.C., Cruz, A.C.R., Marques, M.F.O. \& Gusmão, L.F.P. 2013. Conidial fungi from semi-arid Caatinga biome of Brazil. New and interesting Zanclospora species. - Mycosphere 4: 684-692. http:// dx.doi.org/10.5943/mycosphere/4/4/4

Calduch, M., Gené, J., Guarro, J., Mercado-Sierra, A. \& Castañeda Ruiz, R. 2007. Hyphomycetes from Nigerian rain forests. - Mycologia 94: 127-135. http://dx.doi.org/10.2307/3761852

Caneva, G. \& Rambelli, A. 1981. Danaëa nuovo generi di ifale demaziaceo. - Micologia Italiana 10: 47-49.

Chang, H.-S. 1990. Setiform conidiophore Hyphomycetes from Taiwan. - Botanical Bulletin of Academia Sinica 31: 257-262.

Cruz, da A.C.R., Marques, M.F.O. \& Gusmão, L.F.P. 2007. Fungos anamórficos (Hyphomycetes) da Chapada Diamantina: novos registros para o Estado da Bahia e Brazil. - Acta Botânica Brasilica 21: 847-855. http://dx.doi.org/10.1590/S0102-33062007000400009

Kuthubutheen, A.J. \& Nawawi, A. 1993. Kiliophora: a new genus name for the hyphomycete taxon Danaea. - Mycotaxon 48: 239-247.

Hidayat, I. \& Harahap, I. 2014. The first phylogenetic study of Kiliophora (Fungi, Anamorphic Xylariales).Mycosphere 5: 78-84. http://dx.doi.org/10.5943/mycosphere/5/1/3

Hughes, S.J. \& Kendrick, W.B. 1965. New Zealand Fungi 4. Zanclospora gen. nov. - New Zealand Journal of Botany 3: 151-158. http://dx.doi.org/10.1080/0028825X.1965.10876991

Matsushima, T. 1975. Icones Microfungorum a Matsushima Lectorum. Published by the author, Kobe. Mel'nik, V.A. 2011. Anamorphic fungi of Vietnam. I. - Mikologiya i Fitopatologiya 45: 323-331. (In Russian) Mel'nik, V.A. 2012a. A new species of Andhachandra (hyphomycetes) from Vietnam. - Mycosphere 3: 922-924. http://dx.doi.org/10.5943/mycosphere/3/6/5 
Mel'nik, V.A. 2012b. Phaeoisaria vietnamensis sp. nov. and P. clematidis (hyphomycetes) from Vietnam. Mycosphere 3: 957-960. http://dx.doi.org/10.5943/mycosphere/3/6/10

Mel'nik, V.A. 2013. Three species of hyphomycetes new for mycobiota of Vietnam. - Novosti Sistematiki Nizshikh Rasteniy 47: 122-126. (In Russian)

Mel'nik, V.A. \& Braun, U. 2013. Atractilina alinae sp. nov. and Neosporidesmium vietnamense sp. nov. - two new synnematous hyphomycetes from Vietnam. - Mycobiota 3: 1-9. http://dx.doi.org/10.12664/ mycobiota.2013.03.01

Mel'nik, V.A. \& Crous, P.W. 2014. Braunomyces dictyosporus gen. sp. nov. from Vietnam. - IMA Fungus 5: 1-5. http://dx.doi.org/10.5598/imafungus.2014.05.01.01

Mel'nik, V.A., Novozhilov, Yu.K., Popov, E.S. \& Alexandrova, A.V. 2012. Anamorphic fungi of Vietnam. II. - Mikologiya i Fitopatologiya 46: 347-356. (In Russian)

Mel'nik, V.A., Braun, U. \& Alexandrova, A.V. 2013a. Dactylaria mucoglobifera sp. nov. - a new species from Vietnam. - Schlechtendalia 25: 47-52.

Mel'nik, V.A., Castañeda-Ruiz, R.F. \& Granados, M. 2013b. New species of Heliocephala from Vietnam. Mycotaxon 123: 281-284. http://dx.doi.org/10.5248/123.281

Mel'nik, V.A., Novozhilov, Yu.K., Popov, E.S., Alexandrova, A.V. \& Kovalenko, A.E. 2013c. Anamorphic fungi of Vietnam. III. - Mikologiya i Fitopatologiya 47: 316-320. (In Russian)

Mel'nik, V.A., Novozhilov, Yu.K., Popov, E.S., Alexandrova, A.V., Kuznetsov, A.N. \& Kovalenko, A.E. 2013d. Anamorphic fungi of Vietnam. IV. - Mikologiya i Fitopatologiya 47: 381-389. (In Russian)

Mel'nik, V.A., Novozhilov, Yu.K., Popov, E.S., Alexandrova, A.V., Kuznetsov, A.N. \& Kovalenko, A.E. 2014a. Anamorphic fungi of Vietnam. V. - Mikologiya i Fitopatologiya 48: 181-193. (In Russian)

Mel'nik, V.A., Alexandrova, A.V. \& Braun, U. 2014b. Two new species and new records of hyphomycetes from Vietnam. - Mycosphere 5: 591-600. http://dx.doi.org/10.5943/mycosphere/5/4/11

Mel'nik, V.A., Novozhilov, Yu.K., Popov, E.S., Alexandrova, A.V., Kuznetsov, A.N. \& Kovalenko, A.E. 2015a. Anamorphic fungi of Vietnam. VI. - Mikologiya i Fitopatologiya 49: 31-40. (In Russian)

Mel'nik, V.A., Novozhilov, Yu.K., Popov, E.S., Alexandrova, A.V., Kuznetsov, A.N. \& Kovalenko, A.E. 2015b. Anamorphic fungi of Vietnam. VII. - Mikologiya i Fitopatologiya 49: 226-233. (In Russian)

Mel'nik, V.A., Alexandrova, A.V. \& Popov, E.S. 2015c. Anamorphic fungi on grasses in Vietnam. - Novosti Sistematiki Nizshikh Rasteniy 49: 177-185. (In Russian)

Mel'nik, V.A., Popov, E.S. \& Braun, U. 2016. Neosporidesmium subramanianii sp. nov. from Vietnam. Mycosphere 7: 148-153. http://dx.doi.org/10.5943/mycosphere/7/2/6

Raja, H.A., Stchigel, A.M., Miller, A.N., Crane, J.L. \& Shearer, C.A. 2007. Hyphomycetes from the Smoky Mountains National Park, including three new species. - Fungal Diversity 26: 271-286.

Rao, V.G. \& de Hoog, G.S. 1986. New and critical Hyphomycetes from India. - Studies in Mycology 28: $1-84$.

Schoknecht, J.D. \& Crane, J.L. 1983. Additional Hyphomycetes from freshwater swamps and hammocks. Canadian Journal of Botany 61: 2243-2247. http://dx.doi.org/10.1139/b83-243 